\title{
Synthesis and application of photoproline - a photoactivatable derivative of proline
}

\author{
Benjamin Van der Meijden and John A. Robinson* \\ Chemistry Department, University of Zurich, Winterthurerstrasse 190, 8057 Zurich, Switzerland \\ E-mail: robinson@oci.uzh.ch
}

This paper is dedicated to Professor Heinz Heimgartner

DOI: $\underline{\text { http://dx.doi.org/10.3998/ark.5550190.0012.611 }}$

\begin{abstract}
A convenient synthesis is described of a derivative of L-proline called photoproline, containing a diazirine group at position-4 of the pyrrolidine ring, starting from L-4-hydroxyproline. The use of Fmoc-L-photoproline in the synthesis of a cyclic peptidomimetic antibiotic demonstrates that this photoprobe can be incorporated into synthetic peptides using solid-phase Fmoc chemistry. Photoproline may be of wide value in the preparation of diverse peptide-based photoaffinity probes.
\end{abstract}

Keywords: photoaffinity probe, peptide, receptor, peptidomimetic antibiotic, photolabel

\section{Introduction}

Photoaffinity labelling is a powerful tool for identifying targets of biologically active small molecules. ${ }^{1}$ A key requisite is that a photolabile group can be incorporated into the small molecule, along with a probe to allow later detection of photo-crosslinked receptors, without appreciable loss of biological activity and specificity. One of the most versatile photolabile groups for this purpose is the diazirine, due to its small size, and efficient and irreversible formation of a reactive carbene upon excitation at $350 \mathrm{~nm} .{ }^{2,3}$ Amino acid-based photoaffinity probes, including the phenylalanine analogues $p$-benzoylphenylalanine, $p$-azidophenylalanine and 4-[3-trifluoromethyl]-3H-diazirin-3-yl]-phenylalanine have been known for some time, ${ }^{4-6}$ and more recently the alkyldiazirine amino acid analogs photoleucine, and photomethionine have been described. ${ }^{7,8}$ Here we describe the synthesis and application of a related alkyldiazirine derivative of proline (photoproline), containing a diazirine group at position-4 of the pyrrolidine ring. A photolabile derivative of proline may be of special interest, since proline can have an 
important influence on peptide backbone conformation, and it frequently occurs within the energetically important epitopes in many biologically active peptides and proteins. $^{9}$

\section{Results and Discussion}

The synthesis of Fmoc-protected L-photoproline (photoPro), starting from relatively inexpensive L-trans-4-hydroxyproline, is shown in Scheme-1. The preparation of N-Boc-4-oxoproline $\mathbf{1}$ followed a simple two step procedure ( $i$, Boc protection; $i$, Jones oxidation). ${ }^{10}$ The method used to install the diazirine group finds precedence in earlier published routes to photoleucine and photomethionine. ${ }^{7,8}$ However, the chromatographic purification of $\mathbf{2}$ and $\mathbf{3}$ were inefficient, which resulted in low overall yields (not optimized). The Fmoc-derivative was required to allow incorporation of photoPro into synthetic peptides using standard solid-phase Fmoc peptide chemistry. The diazirine group is stable to the acidic and basic conditions needed in Fmoc solidphase peptide synthesis. It should be noted that the enantiomer (Fmoc-D-photoPro) can be made in a similar way, after epimerization of L-trans-4-hydroxyproline to D-cis-4-hydroxyproline, which is convenient to carry out on a mole scale following a published procedure. ${ }^{11}$
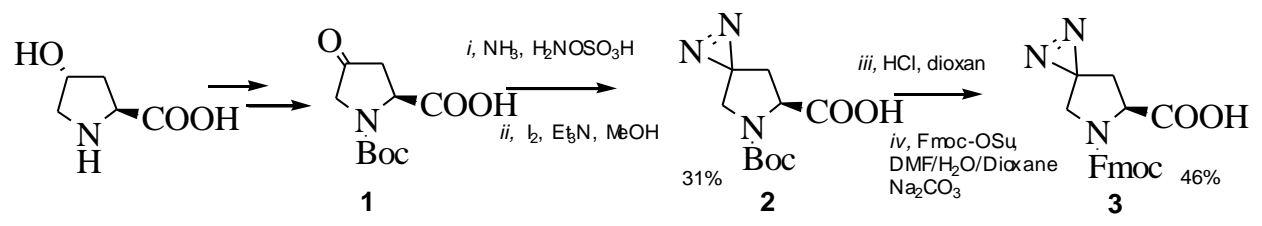

Scheme 1. Synthesis of Fmoc-L-photoproline 3.

We are interested in the application of photoPro to study the mechanism(s) of action of a new family of peptidomimetic antibiotics active against the important human gram-negative pathogen Pseudomonas aeruginosa. ${ }^{12}$ The lead compound (L27-11, (4) Figure 1) shows a minimal inhibitory concentration (MIC) against $P$. aeruginosa, including many multi-drug resistant clinical isolates, in the low nanomolar range.

A cellular target of this peptidomimetic antibiotic was shown recently to be the $\beta$-barrel outer membrane protein LptD. This protein in a complex with the lipoprotein $\mathrm{LptE}$ is known to play a key role in outer membrane $(\mathrm{OM})$ biogenesis by transporting lipopolysaccharide from the periplasm to the outer leaflet of the OM. ${ }^{13}$ Peptidomimetic L27-11 (4) contains a D-Pro-L-Pro template, which is designed to stabilize $\beta$-hairpin-like conformations in the macrocycle. ${ }^{14} \mathrm{We}$, therefore, first set out to replace the L-Pro residue in L27-11 by L-photoPro. This would allow us to investigate the effect of the spiro-diazirine group upon the antimicrobial activity of the peptide. The D-Pro-L-Pro template is very important for the antimicrobial activity of $\mathbf{4}$, so it seemed prudent to check that introducing the spiro-diazirine did not impair the antimicrobial activity of the peptide. 


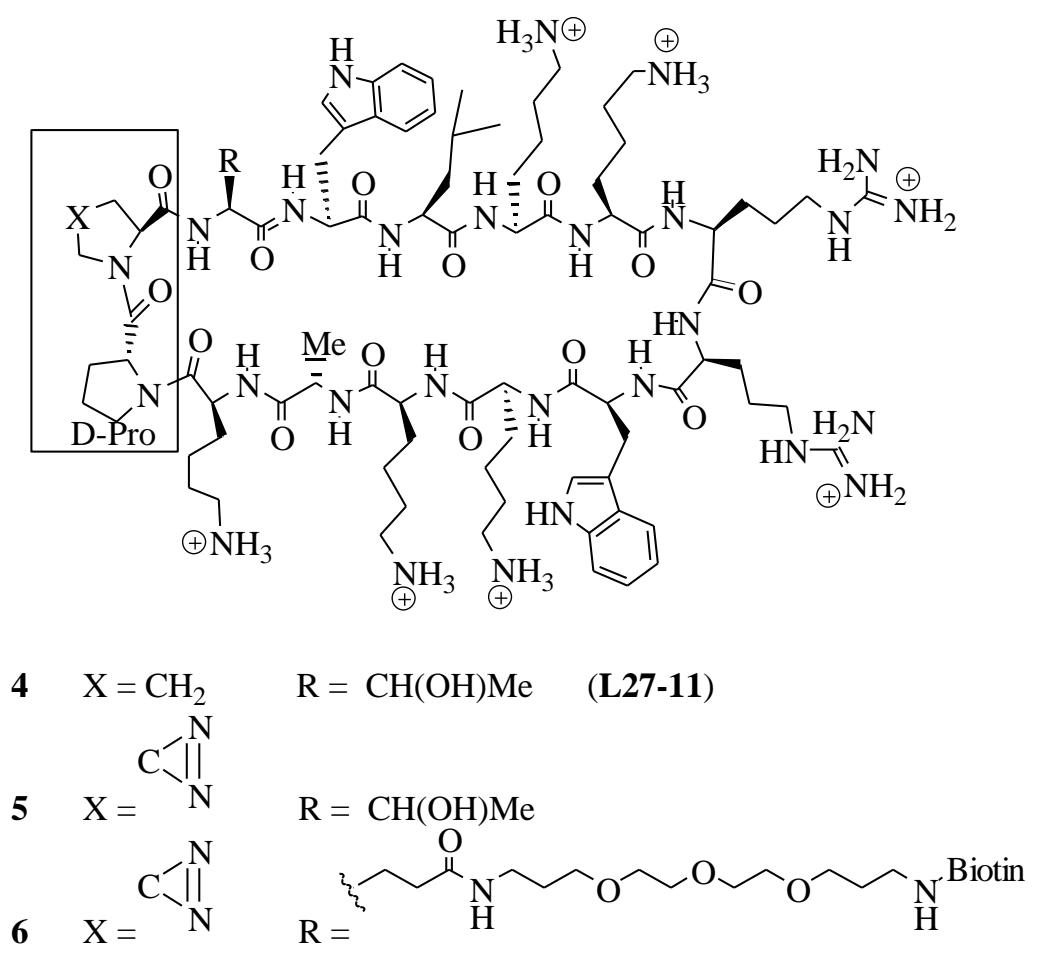

Figure-1. Peptidomimetic antibiotic L27-11 and related derivatives. The D-Pro-L-Pro template in L27-11 is highlighted.

The synthetic approach to the analogue $\mathbf{5}$ is shown in Scheme-2. The peptide synthesis was planned such that the photoPro could be incorporated close to the end of the solid-phase assembly process. After assembly on the resin, the side-chain protected linear peptide chain was cleaved from the resin with $0.8 \%$ TFA, cyclized in dilute DMF solution, and the cyclic product was then deprotected with 95\% TFA. The final product 5 was purified by reverse phase HPLC.

The antimicrobial activity of $\mathbf{5}$ against Pseudomonas aeruginosa ATCC 27853 was assayed using a standard broth microdilution method. The MIC measured in Müller-Hinton broth was $0.008 \mu \mathrm{g} / \mathrm{ml}$, which is essentially identical to that found for L27-11 (4). ${ }^{12}$ Thus, the presence of the diazirine group has no adverse effect on the potent antimicrobial activity of the peptide. In the next step, a photolabelling experiment was planned. For this it was necessary to also introduce a reporter group that can be used to detect the photo-crosslinked target protein. For this, another analogue of this cyclic peptide was made $\mathbf{6}$ using the same method, containing not only photoPro, but also with Thr replaced by a biotin tag ( $N$ - $\gamma$-( $N$-biotinyl-3-(2-(2-(3aminopropyloxy)-ethoxy)-ethoxy)-propyl)-L-glutamine (Glu(biotinyl-PEG), Novabiochem). ${ }^{12}$ We reported recently how this photoprobe $\mathbf{6}$ could be used successfully in a photolabelling experiment to prove that the peptidomimetic antibiotic binds to the OM protein LptD in $P$. aeruginosa. 


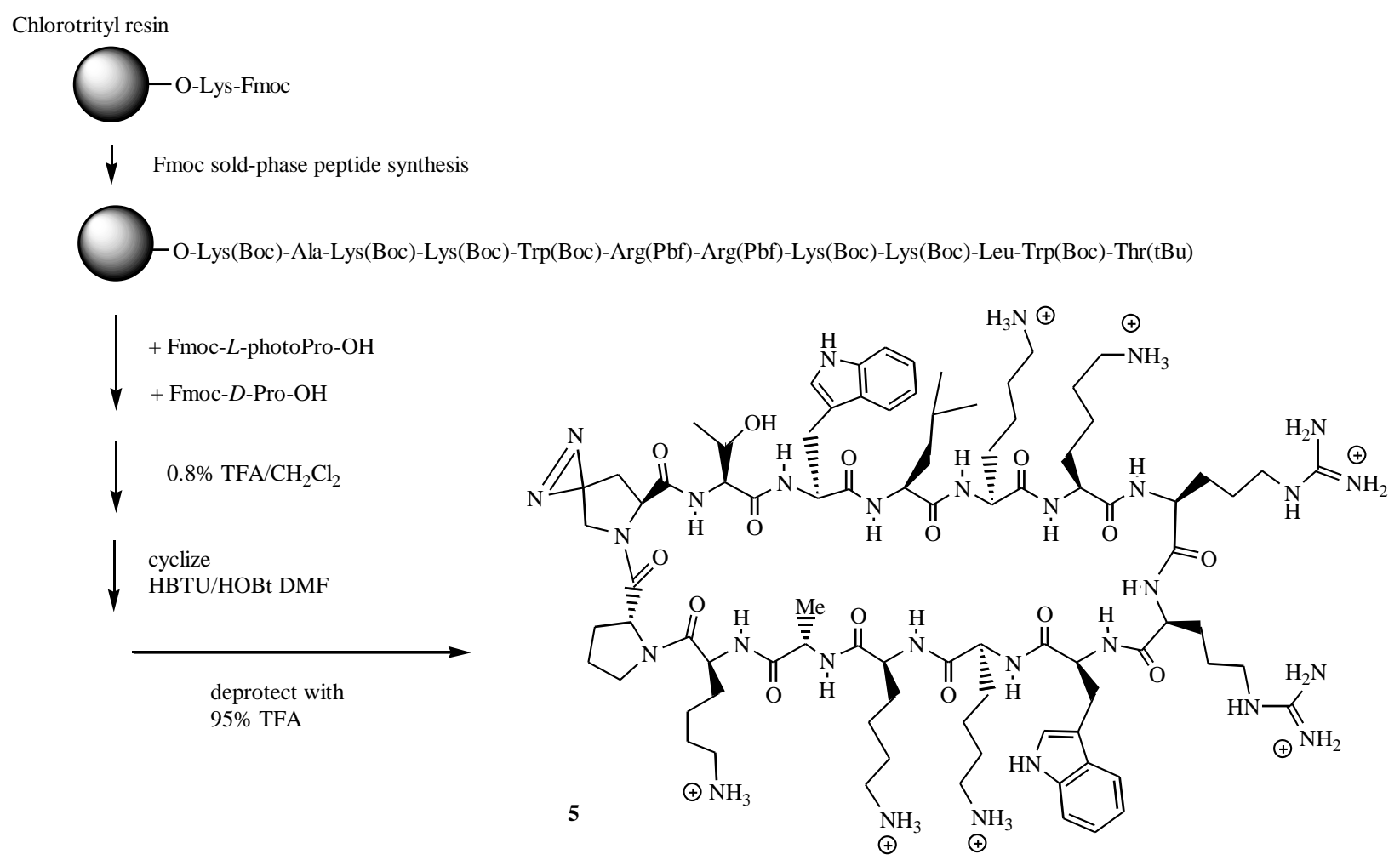

Scheme 2. Synthesis of cyclic peptide 5. The same method was used to prepare 6.

Photoproline appears to have many properties that make it very favorable and interesting for photolabelling experiments. The small steric bulk of the spirodiazirine group is especially noteworthy, as well as the ease and efficiency of photolysis through irradiation with UV light at $350 \mathrm{~nm}$. Since this derivative is readily available using the synthetic method reported here, it may be of wide value in the preparation of diverse peptide-based photoaffinity probes.

\section{Experimental Section}

NMR spectra were recorded on Bruker AMX500 or DRX600 spectrometers at 300K. Chemical shifts are given relative to the internal standard tetramethylsilane. Electrospray mass spectra (ESMS) were recorded on a Finnigan TSQ-700 spectrometer, and high resolution MS on a Bruker MAXIS spectrometer with an accuracy of $\pm 3 \mathrm{ppm}$ at $2 \mathrm{kDa}$.

\section{N-Boc-L-4-Oxoproline (1)}

$N$-Boc-L-4-Hydroxyproline (5 g, $21.6 \mathrm{mmol}$ ) was dissolved in $400 \mathrm{ml}$ acetone. Jones reagent (37 $\mathrm{ml}, 98.8 \mathrm{mmol}$ ) was added dropwise with cooling over $10 \mathrm{~min}$ and the reaction mixture was stirred for $2 \mathrm{~h}$. Methanol $(8.1 \mathrm{ml})$ was added dropwise and the reaction mixture was then filtered through celite and concentrated in vacuo. EtOAc $(270 \mathrm{ml})$ was added and the solution was again filtered through celite. The filtrate was washed with brine $(6 \times 100 \mathrm{ml})$. The organic phase was dried over $\mathrm{Na}_{2} \mathrm{SO}_{4}$ and solvent removed in vacuo. The product crystallized from ethyl acetate. 
Yield: $2.58 \mathrm{~g}(52.1 \%)$. m.p. $159-163^{\circ} \mathrm{C}$ (lit. $\left.160-162^{\circ} \mathrm{C}\right) \cdot{ }^{15}[\alpha]^{20{ }^{\circ} \mathrm{C}} 589 \mathrm{~nm}=+19.7(\mathrm{c}=31.6 \mathrm{mg} / \mathrm{ml}$, acetone). IR: $v\left(\mathrm{~cm}^{1}\right)=1768(\mathrm{~s}), 1751(\mathrm{~s}), 1654(\mathrm{~s}) .{ }^{1} \mathrm{H}-\mathrm{NMR}\left(500 \mathrm{MHz}\right.$, acetone- $\left.\mathrm{d}_{6}\right): \delta(\mathrm{ppm})$ $4.74(\mathrm{t}, \mathrm{J}=8 \mathrm{~Hz}, 1 \mathrm{H}) ; 3.9-3.7(\mathrm{~m}, 2 \mathrm{H}) ; 3.1-3.0(\mathrm{~m}, 1 \mathrm{H}) ; 2.57(\mathrm{~d}, \mathrm{~J}=18 \mathrm{~Hz}, 1 \mathrm{H}) ; 1.46,1.44(2 \times \mathrm{s}$, 9H). ${ }^{13} \mathrm{C}-\mathrm{NMR}$ (acetone-d $\left.\mathrm{d}_{6}\right): \delta(\mathrm{ppm})=209.07+208.39(\mathrm{CO}) ; 173.74+173.49(\mathrm{COOH}), 155.07$ + 154.32 (NCOOR), $80.84\left(\mathrm{OCR}_{3}\right), 57.14+56.51(\mathrm{C} \alpha), 53.39+52.99(\mathrm{C} 5), 41.73+41.19(\mathrm{C} 3)$, $28.44+28.35(\mathrm{Me})$. ES-MS: $m / z 228.0\left(\mathrm{M}-\mathrm{H}^{+}\right)$.

\section{$N$-Boc-proline-4-spiro-3-(3H-diazirine) (2)}

$N$-Boc-L-4-oxoproline (3.08 g, $13.5 \mathrm{mmol})$ was charged into a three necked-flask $(100 \mathrm{ml})$ and ammonia was slowly condensed into the flask. The solution was refluxed for $5 \mathrm{~h}$ with stirring. The solution was cooled with a dry-ice bath and a solution of hydroxylamine- $O$-sulfonic acid in anhydrous methanol $(8 \mathrm{ml}, 1.84 \mathrm{M}, 14.7 \mathrm{mmol})$ was added. The mixture was refluxed for a further $1.5 \mathrm{~h}$. Anhydrous methanol $(18 \mathrm{ml})$ was added while the reaction was cooled with a dryice bath. The solution was stirred overnight to allow the ammonia to evaporate. The resulting slurry was filtered through a sintered glass-funnel and the filter cake was washed twice with methanol $(50 \mathrm{ml})$. The combined methanol phases were treated with triethylamine $(1.88 \mathrm{ml}, 13.6$ $\mathrm{mmol}$ ) and concentrated to $<15 \mathrm{ml}$. Another equivalent of triethylamine (1.88 $\mathrm{ml}, 13.6 \mathrm{mmol})$ was added, the solution was cooled with an ice bath and titrated with a solution of $\mathrm{I}_{2}$ in $\mathrm{MeOH}$ $(0.1 \mathrm{M})$ until the solution remained an orange colour. The solvent was removed in vacuo and the resulting slurry was dissolved in water $(50 \mathrm{ml})$. The solution was acidified to $\mathrm{pH} 2$ and the product was extracted with ethyl acetate $(4 \times 50 \mathrm{ml})$. The organic phase was washed once with brine and dried over $\mathrm{Na}_{2} \mathrm{SO}_{4}$. The solvent was removed in vacuo and product was purified by flash silica chromatography $\left(95 / 5, \mathrm{CH}_{2} \mathrm{Cl}_{2}-\mathrm{MeOH}\right)$. Yield: $0.99 \mathrm{~g}$ (31\%). m.p. $104-107^{\circ} \mathrm{C}$.

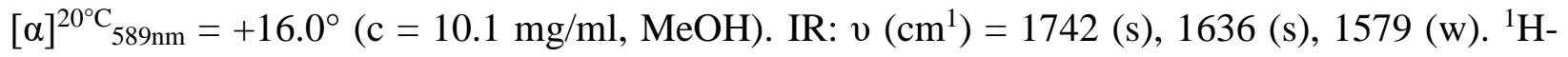
$\operatorname{NMR}\left(600 \mathrm{MHz}, \mathrm{CDCl}_{3}\right): \delta(\mathrm{ppm})=4.66,4.57(2 \times \mathrm{dd}, \mathrm{J}=9.8 \mathrm{~Hz} \& \mathrm{~J}=2.2 \mathrm{~Hz}, 1 \mathrm{H}) ; 3.26-3.22$ $(\mathrm{m}, 1 \mathrm{H}) ; 3.17-3.09(2 \times \mathrm{d}, \mathrm{J}=12.6 \mathrm{~Hz}, 1 \mathrm{H}) ; 2.44-2.34(\mathrm{~m}, 1 \mathrm{H}) ; 1.73-1.66(2 \times \mathrm{dd}, \mathrm{J}=15.2 \mathrm{~Hz} \&$ $\mathrm{J}=2.2 \mathrm{~Hz}, 1 \mathrm{H}) ; 1.46,1.44(2 \times \mathrm{s}, 9 \mathrm{H}) .{ }^{13} \mathrm{C}-\mathrm{NMR}\left(\mathrm{CDCl}_{3}\right): \delta(\mathrm{ppm})=177.63+175.90(\mathrm{COOH})$; $154.66+153.28(\mathrm{CO}) ; 81.89+81.44\left(\mathrm{OCR}_{3}\right) ; 57.73+57.48(\mathrm{C} \alpha) ; 48.40+48.03\left(\mathrm{CN}_{2}\right) ; 33.42+$ $32.19\left(\mathrm{CH}_{2}\right) ; 30.80+30.30\left(\mathrm{CH}_{2}\right) ; 28.24+28.14(\mathrm{Me})$. HR-ES-MS: $m / z\left(\mathrm{M}-\mathrm{H}^{+}\right) 240.0993($ calc. mass $=240.0990)$.

\section{$\mathrm{N}$-Fmoc-L-proline-4-spiro-3-(3H-diazirine) (3)}

$N$-Boc-L-4-Diazirinylproline $(0.99 \mathrm{~g}, 4.11 \mathrm{mmol})$ was dissolved in dioxane $(20 \mathrm{ml})$ and concentrated $\mathrm{HCl}(2 \mathrm{ml})$ was added dropwise. The reaction was stirred for $1.5 \mathrm{~h}$ and the solvent evaporated in vacuo. The sample was dissolved in water and lyophilized to remove excess acid. The residue was dissolved in aq. $\mathrm{Na}_{2} \mathrm{CO}_{3}(9 \% \mathrm{w} / \mathrm{v}, 17.5 \mathrm{ml})$ and 0.9 eq. $O$-Fmoc- $N-$ hydroxysuccinimide (1.24 g) in DMF/dioxane was added. The reaction was shaken for $10 \mathrm{~min}$ and then water $(150 \mathrm{ml})$ was added and unreacted $O$-Fmoc- $N$-hydroxysuccinimide was extracted with diethyl ether and EtOAc. The aqueous phase was acidified to $\mathrm{pH} 2$ and the product was extracted with EtOAc $(5 \times 50 \mathrm{ml})$. The organic phase was dried with $\mathrm{Na}_{2} \mathrm{SO}_{4}$ and the solvent evaporated. The product was purified by flash chromatography first with silica using 94/5/1 
$\mathrm{CH}_{2} \mathrm{Cl}_{2}-\mathrm{MeOH}-\mathrm{AcOH}$, and then using 90/10/0.25, EtOAc-n-hexane-AcOH as eluant. A white powder was obtained after lyophilization. Yield: $672 \mathrm{mg}(46 \%)$. m.p. $113-116^{\circ} \mathrm{C} \cdot[\alpha]^{20^{\circ} \mathrm{C}}{ }_{589 \mathrm{~nm}}=$ $+15.3^{\circ}$ (c = $\left.10.3 \mathrm{mg} / \mathrm{ml}, \mathrm{MeOH}\right)$. IR: v $\left(\mathrm{cm}^{1}\right)=1736$ (s), 1709 (s), 1669 (s), 1580 (w). ${ }^{1} \mathrm{H}-\mathrm{NMR}$ $\left(500 \mathrm{MHz}, \mathrm{CDCl}_{3}\right): \delta(\mathrm{ppm})=7.77-7.72(\mathrm{~m}, 2 \mathrm{H}) ; 7.55-7.53(\mathrm{~m}, 2 \mathrm{H}) ; 7.42-7.28(\mathrm{~m}, 4 \mathrm{H}) ; 4.73-$ $4.70(\mathrm{~m}, 1 \mathrm{H}) ; 4.56-4.41(\mathrm{~m}, 2 \mathrm{H}) ; 4.25,4.19(2 \times \mathrm{t}, \mathrm{J}=6.8 \mathrm{~Hz}, 1 \mathrm{H}) ; 3.29(\mathrm{dd}, \mathrm{J}=21.3$ \& J=12.7 Hz, $1 \mathrm{H}) ; 3.13(\mathrm{~d}, \mathrm{~J}=12.3 \mathrm{~Hz}, 1 \mathrm{H}) ; 2.43-2.32(\mathrm{~m}, 1 \mathrm{H}) ; 1.71,1.56(2 \times \mathrm{dd}, \mathrm{J}=15.0 \mathrm{~Hz} \& \mathrm{~J}=2.4 \mathrm{~Hz}, 1 \mathrm{H})$. ${ }^{13} \mathrm{C}-\mathrm{NMR}\left(\mathrm{CDCl}_{3}\right): \delta(\mathrm{ppm})=176.30+175.53(\mathrm{COOH}), 154.99+153.79(\mathrm{CO}), 143.57+$ 143.47 (Ar), $141.35+141.32$ (Ar), $127.90+127.88$ (Ar), 127.17, $124.96+124.91$ (Ar), 120.10 $+120.05(\mathrm{Ar}), 68.21+67.68(\mathrm{CH}), 57.88+57.35(\mathrm{C \alpha}), 48.36+48.16\left(\mathrm{CN}_{2}\right), 47.09+47.06$ $\left(\mathrm{CH}_{2} \mathrm{O}\right), 33.59+32.31\left(\mathrm{CH}_{2}\right), 30.75+30.12\left(\mathrm{CH}_{2}\right)$. HR-ESI-MS: $m / z\left({\left.\mathrm{M}-\mathrm{H}^{+}\right)}^{+} 362.1149\right.$ (calc. mass $=362.1146$ ).

\section{Peptide Synthesis (5 and 6)}

The linear peptide was synthesized on an ABI433A peptide synthesizer. Fmoc-Lys-OH (1 mmol) was coupled to 2-chlorotritylchloride resin $(1 \mathrm{~g}$, loading $=0.75 \mathrm{mmol} / \mathrm{g})$ in the presence of diisopropylethylamine (DIPEA, $4 \mathrm{mmol}, 4$ eq.) in $\mathrm{CH}_{2} \mathrm{Cl}_{2}(10 \mathrm{ml})$. The unreacted sites on the resin were capped by washing with a mixture of $\mathrm{CH}_{2} \mathrm{Cl}_{2} / \mathrm{MeOH} / \mathrm{DIPEA}$ (17:2:1) followed by $\mathrm{MeOH}$. After removal of the Fmoc-group using 20\% piperidine in N-methyl-2-pyrrolidinone (NMP), chain elongation was performed with Fmoc-protected amino acids, using 20\% piperidine/NMP for Fmoc deprotection, 2-(1H-benzotriazole-1-yl)-1,1,3,3-tetramethyluronium hexafluoro-phosphate/1-hydroxy-benzotriazole (HBTU/HOBt, $0.9 \mathrm{mmol}, 3.6 \mathrm{eq}$.) for activation of 4 equivalents of each amino acid, DIPEA ( 2 mmol, 8 eq.) as base and NMP as solvent. When assembly of the linear peptide chain was complete, the resin was transferred with $\mathrm{CH}_{2} \mathrm{Cl}_{2}$ into a sintered glass funnel, and the last 3 amino acids were coupled manually. Chain elongation was performed with Fmoc-protected amino acids $(0.375$ mmol, 1.5 eq. $)$, using $20 \%$ piperidine/dimethylformamide (DMF) for Fmoc deprotection, 2-(7-aza-1H-benzotriazole-1-yl)1,1,3,3-tetramethyluronium hexafluorophosphate (HATU, $0.3625 \mathrm{mmol}, 1.45$ eq.) for activation, DIPEA (1.25 mmol, 5 eq.) as base and DMF as solvent. Capping was performed after each coupling by treating the resin with a solution of acetic anhydride $(0.95 \mathrm{ml})$, DIPEA $(0.45 \mathrm{ml})$, and HOBt $(40 \mathrm{mg})$ in DMF $(20 \mathrm{ml})$. The peptide was cleaved from the resin by treatment with ice cold $0.8 \% \mathrm{CF}_{3} \mathrm{COOH}$ in $\mathrm{CH}_{2} \mathrm{Cl}_{2}(3 \mathrm{ml})$ for one minute $(8 \mathrm{x})$. The eluate was neutralized immediately with DIPEA $(1 \mathrm{ml})$. The resin was washed 3 times with $\mathrm{CH}_{2} \mathrm{Cl}_{2}$. Subsequently the solvent was removed under high vacuum. For cyclization, the resulting crude product was dissolved in DMF (30 ml). HBTU/HOBt (each 1 mmol, 4 eq.) and DIPEA (2.75 mmol, 11 eq.) were added. The reaction was stirred for $18 \mathrm{~h}$, then DMF was removed under high vacuum. After evaporation, the crude peptide was cooled on ice before adding an ice-cold TFA/TIS/ $\mathrm{H}_{2} \mathrm{O}$ $(95 / 2.5 / 2.5)$ mixture $(10 \mathrm{ml})$. The mixture was stirred for $2 \mathrm{~h}$, then solvent was removed under high vacuum, and the peptide precipitated with ice-cold diethyl ether $(40 \mathrm{ml})$. After washing the precipitate twice with diethyl ether, the product was dried and purified by preparative RP-HPLC on a Waters XBridge ${ }^{\mathrm{TM}}(\mathrm{C} 18,50 \times 19 \mathrm{~mm}, 5 \mu \mathrm{m}, 135 \AA)$ column with a gradient of $10-40 \%$ 
$\mathrm{MeCN} / 0.1 \%$ TFA in $\mathrm{H}_{2} \mathrm{O} / 0.1 \%$ TFA in 7 column volumes. The product was $>95 \%$ pure by analytical reverse phase HPLC. For 5: Retention time $\left(t_{R}\right) 9.1$ min (Grace Vydac C4 column, flow $1 \mathrm{ml} / \mathrm{min}$, gradient $10-50 \% \mathrm{MeCN} / \mathrm{H}_{2} \mathrm{O}+0.1 \%$ TFA over $12.5 \mathrm{~min}$ ); ES-MS $\mathrm{m} / z$ (isotope pattern) $1831+1832+1833+1834[\mathrm{M}+\mathrm{H}]^{+}, \quad 1803+1804+1805+1806 \quad\left[\mathrm{M}+\mathrm{H}_{-} \mathrm{N}_{2}\right]^{+}$(calc. mass 1830.1). For 6: $t_{R}=9.6 \mathrm{~min}($ Grace Vydac C4 column, flow $1 \mathrm{ml} / \mathrm{min}$, gradient $10-50 \%$ $\mathrm{MeCN} / \mathrm{H}_{2} \mathrm{O}+0.1 \%$ TFA over $\left.12.5 \mathrm{~min}\right) ;$ HR-ES-MS $\mathrm{m} / \mathrm{z} \quad[\mathrm{M}+3 \mathrm{H}]^{3+} 763.12339$ $\left(\mathrm{C}_{108} \mathrm{H}_{175} \mathrm{~N}_{33} \mathrm{O}_{20} \mathrm{~S}\right.$ calc. mass for $\left.[\mathrm{M}+3 \mathrm{H}]^{3+} 763.121005\right) ;\left[\mathrm{M}+3 \mathrm{H}-\mathrm{N}_{2}\right]^{3+} 753.78766$.

\section{Antimicrobial assay}

Minimal inhibitory concentrations were determined by a previously published method. ${ }^{12}$

\section{Acknowledgements}

The authors thank the Swiss National Science Foundation and the EU 7th Framework program (project NABATIVI) for financial support, and Annelies Meier for performing antimicrobial assays.

\section{References}

1. Dormán, G.; Prestwich, G. D., Trends Biotech. 2000, 18, 64.

2. Moss, R. A., Acct. Chem. Res. 2006, 39, 267.

3. Blencowe, A.; Hayes, W., Soft Matter 2005, 1, 178.

4. Kauer, J. C.; Erickson-Viitanen, S.; Wolfe, H. R.; DeGrado, W. F., J. Biol. Chem. 1986, 261, 10695.

5. Nassal, M., J. Am. Chem. Soc. 1984, 106, 7540.

6. Schwyzer, R.; Caviezel, M., Helv. Chim. Acta 1971, 54, 1395.

7. Ikeda, Y.; Behrman, E. J., Synth. Comm. 2008, 38, 2276.

8. Suchanek, M.; Radzikowska, A.; Thiele, C., Nature Methods 2005, 2, 261.

9. Williamson, M. P., Biochem. J. 1994, 297, 249.

10. Baldwin, J. E.; Field, R. A.; Lawrence, C. C.; Merritt, K. D.; Schofield, C. J., Tetrahedron Lett. 1993, 34, 7489.

11. Robinson, D. S.; Greenstein, J. P., J. Biol. Chem. 1952, 195, 383.

12. Srinivas, N.; Jetter, P.; Ueberbacher, B. J.; Werneburg, M.; Zerbe, K.; Steinmann, J.; Van der Meijden, B.; Bernardini, F.; Lederer, A.; Dias, R. L. A.; Misson, P. E.; Henze, H.; Zumbrunn, J.; Gombert, F. O.; Obrecht, D.; Hunziker, P.; Schauer, S.; Ziegler, U.; Kach, A.; Eberl, L.; Riedel, K.; DeMarco, S. J.; Robinson, J. A., Science 2010, 327, 1010.

13. Ruiz, N.; Kahne, D.; Silhavy, T. J., Nat. Revs. Microbiol. 2009, 7, 677.

14. Robinson, J. A., Acct. Chem. Res. 2008, 41, 1278.

15. Barraclough, P.; Hudhomme, P.; Spray, C. A.; Young, D. W., Tetrahedron 1995, 51, 4195. 